\title{
Parasitological examination for Trypanosoma theileri infection of cattle from Quirino Province, Philippines
}

This article was published in the following Dove Press journal:

Veterinary Medicine: Research and Reports

20 December 2010

Number of times this article has been viewed

\section{Cherry P Fernandez \\ Abigail M Baticados \\ Waren $N$ Baticados}

Department of Veterinary Paraclinical Sciences, College of Veterinary Medicine, University of the Philippines Los Baños, Laguna, Philippines 403।
Correspondence: Waren Baticados College of Veterinary Medicine, University of the Philippines Los Baños, Laguna, Philippines

Tel +63495362728

Fax +63495362730

Email wnbaticados@uplb.edu.ph
Abstract: Trypanosoma theileri is one of the protozoan parasites reported in cattle and carabaos in the Philippines. The distribution of $T$. theileri infection in livestock in this country is not well established. To date, more than two decades have passed without any new T. theileri prevalence reported in the country. The present study endeavored to determine whether the parasite is endogenously present in cattle from the remote areas of Region II (Cagayan Valley), particularly in the province of Quirino, Philippines and to establish the current parasite prevalence of T. theileri in this province using the blood parasite examination method. A total of 246 field blood samples of cattle was collected from 5/6 (83\%) of the municipalities of Quirino Province, Philippines. Blood parasite examination of Giemsa-stained smears revealed that all samples were negative for the presence of the T. theileri parasite. Given that the mainstay of parasitological examination in the field is the classic blood parasite examination method, the data suggest that the negative results of these examinations can probably be attributed to very low parasitemia.

Keywords: Trypanosoma theileri, blood parasite examination, Quirino Province, Philippines

\section{Introduction}

Livestock are hosts for several trypanosomatid species. The reported trypanosomes in small and large animals include Trypanosoma congolense, T. vivax, T. brucei, T. evansi, and T. theileri. ${ }^{1-3}$ Among the different species, T. theileri is the least studied. This is probably attributable to the described nonpathogenic nature of the parasite. $^{2}$

T. evansi (salivarian) and T. theileri (stercorarian) were the two ubiquitous livestock trypanosome species in cattle and water buffalos reported in the Philippines in past studies. ${ }^{4-7}$ T. evansi is well-studied and known to be pathogenic to horses, whereas $T$. theileri were considered nonpathogenic. ${ }^{2}$ However, it was previously reported that adverse conditions may prime the animal to succumb to trypanosomosis due to $T$. theileri. ${ }^{2,8}$ Several studies implicated $T$. theileri as the etiologic agent of trypanosomosis in cattle. ${ }^{9-12}$ In the report of Pietersma et al, ${ }^{13} T$. theileri parasitemia in a neonatal bison calf was observed. Clinical signs upon presentation included severe dehydration accompanied by hypernatremia, hyperalbuminemia, azotemia, and hyperphosphatemia. Complete blood counts revealed a degenerative left shift, toxic neutrophils, lymphocytosis, mild monocytosis, and severe thrombocytopenia. Since the transmission of $T$. theileri by tabanid flies was unlikely at this young age, it was deduced that the animal was transplacentally infected.

The reports of parasite prevalence in the field, as with the succeeding data, resulted from the blood parasite examination (BPE) method. T. theileri infection has likewise submit your manuscript | www.dovepress.com

Dovepress

DOI: 10.2147/VMRR.S16169
Veterinary Medicine: Research and Reports 2010:I 3-6

(C) 2010 Fernandez et al, publisher and licensee Dove Medical Press Ltd. This is an Open Access article which permits unrestricted noncommercial use, provided the original work is properly cited. 
been reported in the European continent. In Zaragoza, Spain a sample prevalence of $33.3 \%$ (4/12) T. theileri infection was obtained from a Spanish bullfighting farm located in the Seville Province. ${ }^{14}$ A prevalence of 3.2\% (31/970) was also recorded in cattle from the African continent, particularly Mafia Island, Tanzania. ${ }^{15}$ According to Kennedy, ${ }^{16}$ the infection had also reached North America and surveys showed that the prevalence in the United States and parts of Canada ranged from $10 \%$ to $80 \%$. The study also reported the first documented trypanosomes in adult cattle in Alberta, Canada.

On the Asian continent, difficulty of microscopic detection of the $T$. theileri parasite in blood smears is commonly encountered and affects the prevalence data. In Iran, the hemoflagellate parasite was not detected when using blood parasite examination method in any of the 238 cattle in the survey. ${ }^{17}$ Conversely, in the Philippines the latest published report of sample prevalence of $T$. theileri infection in cattle, from the National Capital Region, was $12 \%(12 / 100) .{ }^{5}$ However, the distribution of $T$. theileri infection in livestock in this country is not well established; to date, more than two decades have passed without any new T. theileri prevalence reported in the Philippines. The current study endeavored to determine whether the parasite is endogenously present in cattle from the remote areas of Region II (Cagayan Valley), particularly in the province of Quirino, Philippines and to establish the current parasite prevalence of $T$. theileri in this province using the BPE method.

A total of 246 field blood samples of cattle from five out of the six municipalities of Quirino province were found to be negative for the T. theileri hemoparasite. Based on the corroborating findings of repeated BPE of the samples, the study suggests that the negative results are probably attributed to very low parasitemia.

\section{Materials and methods}

\section{Animals and sampling site}

A total of 246 cattle (Bos taurus) was randomly sampled from five out of six municipalities of Quirino. The chosen municipalities included Diffun, Cabarroguis, Saguday, Aglipay, and Maddela. The sample size was determined using a formula previously described ${ }^{18}$ (Figure 1).

\section{Blood collection and blood parasite examination}

Using $5 \mathrm{~mL}$ ethylenediaminetetraacetic acid (EDTA)impregnated vacutainer tubes, $3-5 \mathrm{~mL}$ of blood were collected from the jugular vein of cattle. Blood smears were immediately prepared and the rest of the blood samples were stored at $-40^{\circ} \mathrm{C}$ until required for molecular processing.

The smear samples were stained with Giemsa ${ }^{\circledR}$ (Medic Diagnostic Reagents, Quezon City, Philippines) and the whole slide examined following the method of Pritchard and Kruse ${ }^{19}$ using a microscope (Olympus, Lehigh Valley, NY) at high power $(40 \times)$ and oil immersion $(100 \times)$ objectives. Slide examination was replicated three times.

\section{Results and discussion}

Two reported species of trypanosomes are known to infect livestock in the Philippines. This study focused on T. theileri, which is the lesser studied species. Despite the scarcity of information pertaining to $T$. theileri infection in the country, reports of its opportunistic potential to cause morbidity and its importance in disease diagnosis against surra, warranted further investigation of the parasite.

The use of detection systems based on trypanosomal genomic DNA has revolutionized the diagnosis of trypanosomes. Polymerase chain reaction (PCR) has been proven to be more sensitive than BPE in detecting trypanosome genomic DNA in the animal or vector host. ${ }^{20}$ According to Masiga et $\mathrm{al}^{21}$ and Solano et al, ${ }^{20} \mathrm{PCR}$ is sensitive enough to be able to detect even one trypanosome genomic DNA per mL of blood. Furthermore, DNA-based methods for diagnosis have generally facilitated epidemiological studies of trypanosomes. ${ }^{22}$ However, in the Philippines, the use of PCR technology is currently limited to academic and specialized government institutions. The possibility of field applications is currently being hampered by economic issues and questions, especially pertaining to its suitability as a diagnostic test in the field or countryside.

The predominant diagnostic tool for field diagnosis of trypanosomes in most municipalities in the country is still microscopic examination or BPE. It is probably the most economical and easiest technique for detection of trypanosomes. Similarly, in other countries, the diagnosis of trypanosomosis in mammalian hosts essentially relies on visualization of the parasites in the blood smears. ${ }^{23,24}$ Results of the current study showed that all Giemsa-stained blood smears were negative for $T$. theileri blood stream forms. These findings align with previous data stating that although $T$. theileri are cosmopolitan blood parasites of cattle, they are rarely observed in direct blood smears. ${ }^{25}$ Moreover, according to Nantulya, ${ }^{1}$ standard techniques such as BPE are not sufficiently sensitive since they offer 
A

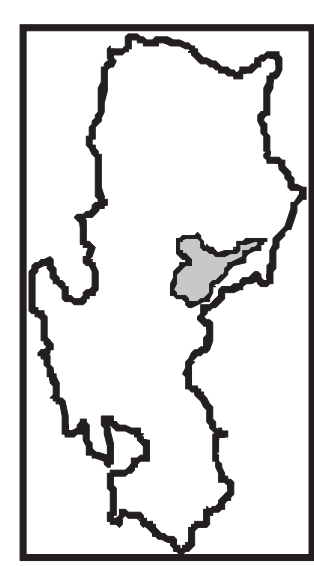

B

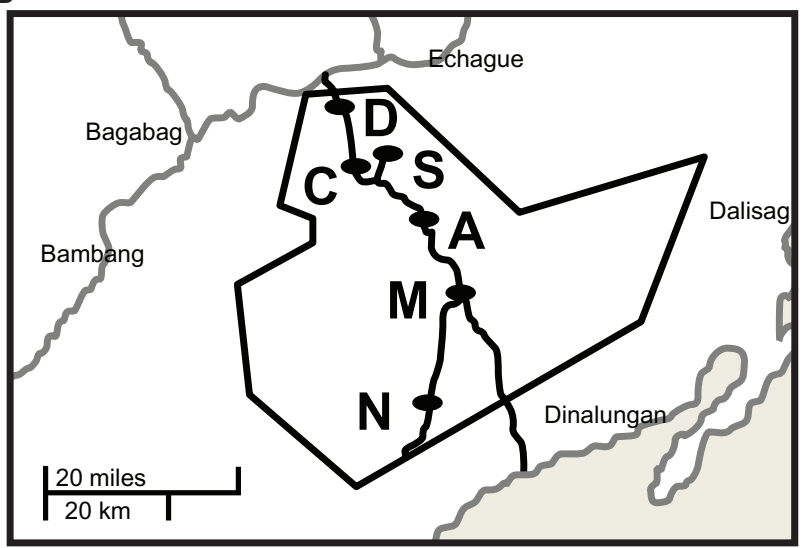

C

\begin{tabular}{|c|c|c|c|}
\hline Municipality & $\begin{array}{c}\text { Total cattle } \\
\text { population }\end{array}$ & $\begin{array}{c}\text { Letter } \\
\text { identification }\end{array}$ & $\begin{array}{c}\text { Sample } \\
\text { size }\end{array}$ \\
\hline Diffun & 2,168 & D & 77 \\
\hline Cabarroguis & 719 & C & 26 \\
\hline Saguday & 1,184 & S & 42 \\
\hline Aglipay & 1,894 & A & 68 \\
\hline Maddela & 923 & M & 33 \\
\hline TOTAL & 6,888 & & 246 \\
\hline
\end{tabular}

Figure I Randomly selected animals and sampling sites in Quirino Province, Philippines. A) Map of the northern part of the Philippines-Luzon. The gray area represents the location of Quirino Province. B) Map of Quirino Province. Black dots represent the sampled (D, Diffun; C, Cabarroguis; S, Saguday; A, Aglipay; and M, Maddela) and nonsampled (N, Nagtipunan) municipalities. C) Total population and sample size of cattle.

only $50 \%$ probability of positively identifying the parasite during microscopic examination of the blood smears. In addition, parasitological examinations are limited during chronic or subclinical cases wherein there is characteristically very low parasitemia. ${ }^{1,2}$

In summation, based on the corroborating results of repeated blood parasite examination of the samples, the study suggests that the negative results are probably attributable to very low parasitemia.

\section{Acknowledgments}

The authors would like to express their deepest and most sincere appreciation to the veterinary and livestock personnel and individuals who, in one way or another, helped in the completion of this undertaking, including: Dr Marcelino G Delson Jr, Mr Crispin A Fernandez, Mr Venancio R Sadang III, Mr Marcillus Abellanosa, Dr Manuel Galang, Dr Roberto Busania, Mr Sandy Valencia, Mr Wijieson Valencia, Mrs Remedios P Fernandez, and CVUPROS staff.

\section{Disclosure}

The authors report no conflicts of interest in this work.

\section{References}

1. Nantulya VM. Trypanosomiasis in domestic animals: the problems of diagnosis. Rev Sci Tech Off Int Epiz. 1990;9:357-367.

2. Soulsby EJL. Helminths, Arthropods, and Protozoa of Domesticated Animals. 7th ed. London, UK: Baillière Tindall; 1982;514:532-536.

3. Townsend J, Duffus WPH. Trypanosoma theileri: antibody-dependent killing by purified populations of bovine leukocytes. Clin Exp Immunol. 1982;48:289-299.

4. Manuel MF. Sporadic outbreaks of Surra in the Philippines and its economic impact. J Protozool Res. 1998;8:131-138.

5. Manuel MF, Encomienda IQ. Biomorphological characteristics of Trypanosoma evansi and T. theileri of some domestic animals. Philipp $J$ Vet Med. 1987;24:69-72.

6. Lostrie-Trussart N, Letesson JJ, Didembourg CH, Depelchin A. The use of amphotericin B in prevention of Trypanosoma theileri growth in bovine cell culture. Vet Parasitol. 1987;29:9-17.

7. Hall HTB. Diseases and Parasites of Livestock in the Tropics. 2nd ed. Intermediate Tropical Agriculture Series. Harrow, UK: Longman Scientific \& Technical; 1985:197-204.

8. Mansfield JM. Taxonomy, kinetoplastids, and flagellates of fish. Parasitic Protozoa. 1977;1:310-315.

9. Seifi HA. Clinical trypanosomosis due to Trypanosoma theileri in a cow in Iran. Trop Anim Health Prod. 1995;27:93-94. 
10. Doherty ML, Wnidle H, Voorheis HP, et al. Clinical diseases associated with Trypanosoma theileri infection in a calf in Ireland. Vet Rec. 1993; 132:653-656.

11. Farrar RG, Klei TR. Prevalence of Trypanosoma theileri in Lousiana cattle. J Parasitol. 1990;76:734-736.

12. Ward WH, Hill MW, Mazlin ID, Foster CK. Anaemia associated with a high parasitaemia of Trypanosoma theileri in dairy cow. Aust Vet J. 1984;61:324.

13. Pietersma AL, Ogunremi O, Desrochers A. Parasitemia in a bison calf. Vet Clin Pathol. 2004;33(3):173-176.

14. Villa A, Gutierrez C, Gracia E, et al. Presence of Trypanosoma theileri in Spanish cattle. Animal Biodiversity and Emerging Diseases Prediction and Prevention. 2008:352-354.

15. Goossens B, Mbwambo H, Msangi A, Geysen D, Vreysen M. Trypanosomosis prevalence in cattle on Mafia Island (Tanzania). Vet Parasitol. 2006;139:74-83.

16. Kennedy MJ. Trypanosoma theileri in cattle of central Alberta. In: Cross-Canada disease report. Can Vet J. 1988;29:937-938.

17. Niak A. The incidence of Trypanosoma theileri among cattle in Iran. Trop Anita Hlth Prod. 1978;10:26-27.

18. Thrusfield M. Veterinary Epidemiology. London, UK: Butterworth and Co. Ltd; 1986:154-155.
19. Pritchard MH, Kruse GOW. The Collection and Preservation of Animal Parasites. Lincoln, NE: University of Nebraska Press; 1982:7, 33.

20. Solano P, Michel JF, Lefrançois T, et al. Polymerase chain reaction as a diagnosis tool for detecting trypanosomes in naturally infected cattle in Burkina Faso. Vet Parasitol. 1999;86:95-103.

21. Masiga DK, McNamara JJ, Laveissière C, Truc P, Gibson WC. A high prevalence of mixed trypanosome infections in tsetse flies in Sinfra, Côte d'Ivoire, detected by DNA amplification. Parasitology. 1996; 112:85-90.

22. Mugittu KN, Silayo RS, Majiwa PAO, Kimbita EK, Mutayoba BM, Maselle R. Application of PCR and DNA probes in the characterization of trypanosomes in the blood of cattle in farms in Morogoro, Tanzania. Vet Parasitol. 2001;94:177-189.

23. Boulange A, Katende J, Authie E. Trypanosoma congolense: expression of a heat shock protein 70 and initial evaluation as a diagnostic antigen for bovine trypanosomosis. Exp Parasitol. 2002;100:6-11.

24. Reid SA. Trypanosoma evansi control and containment in Australasia. Trends Parasitol. 2002;18:219-223.

25. Levine ND. Flagellates: the hemoflagellates. Veterinary Protozoology. Ames, IA: The Iowa State University Press; 1985:46.
Veterinary Medicine: Research and Reports

\section{Publish your work in this journal}

Veterinary Medicine: Research and Reports is an international, peer-reviewed, open access journal publishing original research, case reports, editorials, reviews and commentaries on all areas of veterinary medicine. The manuscript management system is completely online and includes a very quick and fair peer-review system. Visit http://www.

\section{Dovepress}

dovepress.com/testimonials.php to read real quotes from published authors. 